Lisboa, 22 de Março de 2004

\title{
Exmo. Senhor
}

Prof. Harley Bicas,

Presidente do Conselho Editorial do Arquivos Brasileiros de Oftalmologia,

Divulgação do Resumo da Proposta de Projecto de Cooperação Luso-Brasileira "Identificação e Estudo de Alterações Cromossómicas em Anomalias Oculares"

Agradeço a sua amabilidade de possibilitar a divulgação do resumo da proposta de projecto de colaboração Luso-Brasileira "Identificação e Estudo de Alterações Cromossómicas em Anomalias Oculares" nos Arquivos Brasileiros de Oftalmologia.

O texto previamente enviado foi elaborado para divulgação em Portugal. Presentemente, além das várias famílias com translocações em estudo, estamos a desenvolver uma rede de médicos de referência que vão-nos enviar os doentes para pesquisa de alterações cromossómicas.

O texto do resumo agora enviado (em anexo) foi revisto e as partes referentes à colaboração e participação no projecto foram clarificadas e realçadas.

Com a esperança de considerarem o resumo agora enviado suficientemente claro para poder ser publicado nos Arquivos Brasileiros de Oftalmologia, subscrevo-me,

Atenciosamente.

Dezso David, Ph.D. Investigador do INSA

Centro de Genética Humana Instituto Nacional de Saúde "Dr. Ricardo Jorge"

\section{Projecto de Colaboração Luso-Brasileiro Identificação e Estudo de Alterações Cromossómicas em Anomalias Oculares}

\section{Introdução}

A incidência de rearranjos cromossómicos equilibrados de novo é de aproximadamente 1 em 2500 recém-nascidos, dos quais cerca de $6 \%$ se encontram associados a anomalias fenotípicas. O mapeamento físico e a clonagem dos pontos de quebra destes rearranjos cromossómicos associados a anomalias congénitas, e especialmente de translocações equilibradas, são importantes meios para identificação de novos genes envolvidos em patologias humanas. O número de genes ligados a patologias oculares identificados através da caracterização de anomalias cromossómicas é considerável. Recentemente, a aplicação desta metodologia no Centro de Genética Humana do
Instituto Nacional de Saúde Dr. Ricardo Jorge (INSA), Lisboa, Portugal, realçou, por um lado, a importância da identificação de famílias com anomalias oculares associadas a translocações cromossómicas, e por outro lado, o alcance desta abordagem para o conhecimento de novos genes associados a patologias oftálmicas. (David et al. Genomics, 81(5):489-503, 2003).

\section{Objectivo}

O objectivo deste projecto é a identificação de novos genes causadores de anomalias oculares congénitas, através do estudo de alterações cromossómicas identificadas em indivíduos com patologias oculares. 


\section{Informações Adicionais}

Em termos gerais, não existe uma definição clara de quais os doentes com anomalias oculares com indicação para pesquisa de alterações cromossómicas. No entanto, a associação de qualquer anomalia ocular congénita com: uma malformação adicional, abortos de repetição, atraso de desenvolvimento psicomotor ou fácies dismorfico entre outros, será com certeza uma indicação para pesquisa de alterações cromossómicas. Podemos sugerir como mais indicadas, as anomalias oculares graves, microftalmias, anoftalmias, malformações congénitas da câmara anterior do olho (ASD), anomalia de Peters, etc. Em função dos genes normalmente envolvidos, a maioria dos casos a estudar serão patologias congénitas (genes com função durante o desenvolvimento embrionário). No entanto, deverá ter-se em atenção que as manifestações clínicas poderão também ter início só após o nascimento ou durante a vida adulta (genes com função após o nascimento ou de desenlace tardio). Nestes indivíduos, geralmente, a patologia ocular não se encontra associada a outras anomalias.

Os indivíduos a analisar serão, geralmente, os primeiros membros afectados da família. Os filhos dos propositi, com alterações cromossómicas, serão todos afectados em formas dominantes, mas tal poderá não acontecer se estivemos em presença de formas recessivas. É ainda importante a existência de, pelo menos, dois indivíduos afectados na família, embora este critério não seja exclusivo. É de salientar, também, que, a segregação aleatória dos cromossomas poderá originar indivíduos com alterações cromossómicas desequilibradas (monosomia ou trisomia parcial) com um quadro clínico diferente e consideravelmente mais grave.

\section{Participação no projecto de Colaboração}

A colaboração neste projecto poderá desenvolver-se a dois níveis, nomeadamente, ao nível da identificação de famílias com anomalias oculares associadas a alterações cromossómicas e/ou ao nível da caracterização destas alterações cromossómicas.

Nas famílias com alterações cromossómicas previamente identificadas ou que venham a ser identificadas durante o projecto, far-se-à o estudo citogenético familiar. Será também iniciada, em estreita colaboração com os grupos brasileiros, por técnicas de citogenética e biologia molecular, a caracterização das alterações identificadas, i.e. mapeamento e caracte- rização dos pontos de quebra, identificação e caracterização de genes candidatos, etc.

Todos os dados familiares obtidos, assim como os resultados do estudo, são totalmente confidenciais. Estes resultados serão apresentados à comunidade científica nacional ou internacional sempre como resultado do trabalho de colaboração estabelecido.

Para mais informações relativamente aos formulários, condições de envio, ou outras, por favor contactar o responsável do projecto.

\section{Resultados Esperados}

Este projecto permitirá a identificação de novos genes candidatos para as anomalias oculares estudadas, o melhor conhecimento da patologia molecular destas, assim como o diagnóstico clínico e um aconselhamento familiar melhorados.

\section{Contacto}

Para mais informações sobre esta colaboração por favor contactar: Dezso David, Ph.D., Investigador do Centro de Genética Humana do Instituto Nacional de Saúde Dr. Ricardo Jorge, Av. Padre Cruz, 1649-016 Lisboa, Portugal.

Fax: (+351) 217526410; Telephone: (+351) 217519322;

e-mail: dezso.david@insa.min-saude.pt

Neste projecto participam ainda:

- Dr. Hildeberto Correia do Laboratório de Citogenética do Centro de Genética Humana do INSA;

- Dr. Eduardo Silva, do Instituto Biomédico de Investigação da Luz e Imagem, Coimbra

\section{Bibliografia}

David D, Cardoso J, Marques B, Marques R, Silva E. D, Santos H, B Maria G. Molecular characterization of a familial translocation implicates disruption of HDAC 9 and possible position effect on TGFB2 in the pathogenesis of Peters' anomaly. Genomics, 81(5):489-503, 2003.

Fantes J, Ragge NK, Lynch SA, McGill NI, Collin JR, Howard-Peebles PN, Hayward C, Vivian AJ, Williamson K, van Heyningen V, FitzPatrick DR. Nat Genet. 33(4):461-3, 2003.

Jamieson RV, Gaunt L, Donnai D, Black GC, Kerr B, Stecko O, Black GC. Chromosomal translocation in a family with ocular anomalies: indications for karyotype analysis. Br J Ophthalmol. 87(5):646-8, 2003.

Lyon MF, Jamieson RV, Perveen R, Glenister PH, Griffiths R, Boyd Y, Glimcher LH, Favor J, Munier FL, Black GC. A dominant mutation within the DNA-binding domain of the bZIP transcription factor Maf causes murine cataract and results in selective alteration in DNA binding. Hum Mol Genet. 12(6):585-94, 2003.

\section{Ao enviar um artigo para publieação, leia ATENTAMENTE as instruções para autores, constante no final de cada fascículo.}

